
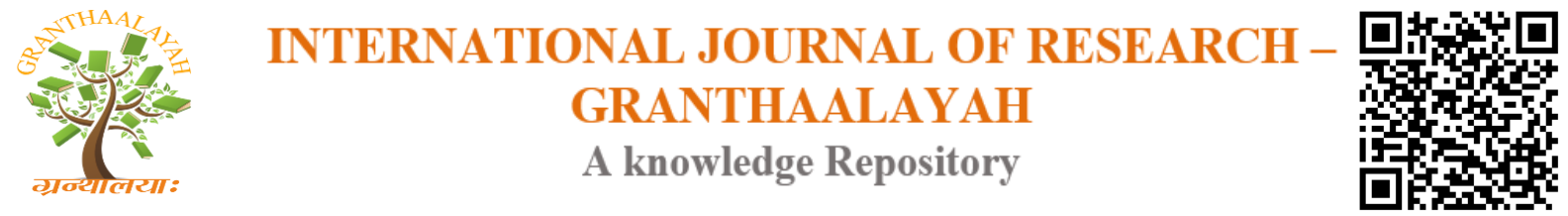

Science

\title{
USE OF BIOTECHNOLOGY IN LIVESTOCK PRODUCTION AND PRODUCTIVITES: A REVIEW
}

\author{
Getachew Bekele Fereja ${ }^{* 1}$ \\ ${ }^{* 1}$ Department of Animal Science, College of Agriculture and Natural Resource, Gambella \\ University, PO Box 126, Gambella, ETHIOPIA
}

DOI: https://doi.org/10.29121/granthaalayah.v4.i6.2016.2643

\section{ABSTRACT}

A major benefit of agricultural research and technology is that the purchasing power of the poor increases, because both average incomes and access to staple food products are improved. The use of biotechnology will lead to a distinct shift in the economic returns from livestock. Livestock production currently accounts for about $43 \%$ of the gross value of agricultural production. In developed countries livestock accounts for more than half of agricultural production, while in developing countries the share is about one-third. This latter share, however, is rising quickly because of rapid increases in livestock production resulting from population growth, urbanization, changes in lifestyles and dietary habits and increasing disposable incomes. Therefore the objective of this review paper was to investigate the use of biotechnology in animal production and productivities. Biotechnology is regarded as a means to the rapid increase in agricultural production through addressing the production constraints of small-scale or resource-poor farmers who contribute more than $70 \%$ of the food produced in developing countries. Agricultural biotechnology as the solution to the problem of global food insecurity has also been reviewed by Soetan. Agricultural biotechnology has the potential to address some of the problems of developing countries like food insecurity, unfavorable environmental and climatic conditions etc mentioned above and also improve agricultural productivity.

Keywords:

Biotechnology, improvement, livestock, production.

Cite This Article: Getachew Bekele Fereja, "USE OF BIOTECHNOLOGY IN LIVESTOCK PRODUCTION AND PRODUCTIVITES: A REVIEW" International Journal of Research Granthaalayah, Vol. 4, No. 6 (2016): 100-109.

\section{INTRODUCTION}

The use of biotechnology will lead to a distinct shift in the economic returns from livestock. Livestock production currently accounts for about $43 \%$ of the gross value of agricultural production. In developed countries livestock accounts for more than half of agricultural 
production, while in developing countries the share is about one-third. This latter share, however, is rising quickly because of rapid increases in livestock production resulting from population growth, urbanization, changes in lifestyles and dietary habits and increasing disposable incomes. Globally, livestock production is growing faster than any other sector, and by 2020 livestock is predicted to become the most important agricultural sector in terms of added value. Although it is hoped that biotechnology will improve the life of every person in the world and allow more sustainable living, crucial decisions may be dictated by commercial considerations and the socioeconomic goals that society considers to be the most important.

There has been a constant increase in the demand of livestock and livestock related products worldwide. However, today the world production merely meets the demand to a significant extent. No wonder this is made scientists to try to improve livestock and livestock associated derivatives. With genetic manipulation and related technologies gaining prominence more and more, research interests to improve livestock using genetic engineering has become a buzzword today; day by day more focuses are being put in this regard (Onteru et al. 2010). Therefore the objective of this review paper was to investigate the use of biotechnology in animal production and productivities.

\section{GENETIC ENGINEERING}

The first successful gene transfer method in animals (mouse) was based on the microinjection of foreign DNA into zygotic pronuclear. However, microinjection has several major shortcomings including low efficiency, random integration and variable expression patterns which mainly reflect the site of integration. Research has focused on the development of alternate methodologies for improving the efficiency and reducing the cost of generating transgenic livestock.

These include sperm mediated DNA transfer (Baccetti \& Spadafora 2000, Chan et al. 2000, Khoo 2000, Lauria \& Gandolfi 1993, Lavitrano et al. 2003, Lavitrano et al. 1997, Maione et al. 1998, Nakanishi \& Iritani 1993, Shamila \& Mathavan 1998, Smith \& Spadafora 2005), intracytoplasmic injection (ICSI) of sperm heads carrying foreign DNA injection or infection of oocytes (Cai et al. 2011, Li et al. 2012, Lu et al. 2011, Umeyama et al. 2012, Yu et al. 2011) and/or embryos by different types of viral vectors (Ishii et al. 2004, Kimura et al. 1994), RNA interference technology (RNAi) (Wise et al. 2008) and the use of somatic cell nuclear transfer (SCNT) (Mir et al. 2005). To date, somatic cell nuclear transfer, which has been successful in 13 species, holds the greatest promise for significant improvements in the generation of transgenic livestock. Furthermore, there are some common ways of manipulating the animal genome.

\subsection{METHOD RETROVIRAL VECTOR}

Of the various gene transfer method, the retroviral vectors has the advantage of being an effective means of integrating_the transgene into the genome of a recipient cell. However, these, vectors can transfer only small pieces ( $~ 8$ kilobases) of DNA, which, because of the size constraint, may lack essential adjacent sequences for regulating the expression of the transgenic (Squire et al. 1989). Major drawback of this method is that the retrovirus may well revert to a pathogenic form to cause diseases such as cancer etc. 


\section{THE BIOTECHNOLOGY IMPLICATIONS}

A major benefit of agricultural research and technology is that the purchasing power of the poor increases, because both average incomes and access to staple food products are improved. Studies by economists have provided empirical support for the proposition that growth in the livestock sector affects the whole economy Birthal P.S., Kumar A., Ravi Shankar A. \& Pandey U.K. (1999). Rapid growth of livestock production has stimulated demand for and increased the value of land, labour and nonagricultural goods and services, thereby leading to overall economic growth Delgado C.L., Hopkins J. \& Kelly V.A. (1998).

\subsection{REPRODUCTIVE TECHNOLOGIES}

Assessing the fertilization capacity of sperms, sexing sperms, synchronization and fixed-time insemination, super ovulation, embryo transfer (ET) and in vitro embryo production (IVEP) are additional techniques that can improve reproductive efficiency and pregnancy rates. Reproductive technologies can also be used to control reproductive diseases if procedures and protocols are accurately followed Madan M.L. (2002). The main objectives of using reproductive biotechnologies in livestock are to increase production, reproductive efficiency and rates of genetic improvement. Over the years, many options have become available for managing the reproduction of the major large and small ruminants. Artificial insemination (AI) and preservation of semen are the main technologies that are used extensively.

\subsubsection{ARTIFICIAL INSEMINATION}

The conception rate in field AI programmes in developing countries is very low, and therefore the desired effect in terms of animal improvement has not been achieved. Most semen banks still evaluate semen on the basis of sperm motility, even though significant advances have been made in techniques for semen evaluation. Although detailed guidelines are available regarding the processing, storage and thawing of cattle semen Vishwanath R. \& Shannon P. (2000) and buffalo semen Sansone G., Nastri M.J.F. \& Fabbrocini A. (2000). the processing and handling procedures in laboratories processing semen are often inadequate. Only when farmers have access to considerably better technical and organizational facilities will AI become more effective.

\subsubsection{EMBRYO TRANSFER}

One of the major reproductive technologies that can facilitate genetic improvement in cattle is ET. Unfortunately, commercial ET programmes are limited by the high variability in the ovarian follicular response to gonadotropin stimulation. Multiple ovulation and embryo transfer (MOET) takes AI one step further, in terms of both the possible genetic gains and the level of technical expertise and organization required. In 2001, 450,000 embryos were transferred globally, mainly in dairy cattle, with $62 \%$ being transferred in North America and Europe, $16 \%$ in South America and $11 \%$ in Asia. The main potential advantage of MOET for developing countries is that the elite females of local breeds can be identified, and bulls can be produced from them for use in a field programmed of breed improvement. 
Zebu cattle and buffaloes in developing countries exhibit less consistent follicular dynamics after superovulation than Bos taurus in the developed world. However, over the last 10 to 15 years, the number of transferable embryos produced by zebu donors has increased from 2.4 to 5.8 embryos per flush in the late 1980 s to 5.6 to 9.9 embryos per flush in Barros C.M. \& Nogueira M.F.G. (2001).

\subsubsection{IN VITRO PRODUCTION OF EMBRYOS}

Since the birth of the first buffalo calf from an in vitro fertilized oocyte, a number of publications have described the effects of different protocols and media on oocyte and embryo development. Two extensive reviews have been published recently. However, the practical use of IVEP is limited by high production costs and the low overall efficiency under field conditions. High rates of maturation (70\% to $90 \%$ ), fertilisation $(60 \%$ to $70 \%$ ) and cleavage (40\% to $50 \%$ ), and moderate to low rates of blastocyst formation (15\% to $30 \%)$ and calf production $(10.5 \%)$ have been reported in the literature Nandi S., Raghu H.M., Ravindranatha B.M. \& Chauhan M.S. (2002).

\subsubsection{SEMEN AND EMBRYO SEXING}

Although these biotechnologies do not dramatically increase the rate of genetic gain, they can increase production efficiency. At a research level, they are being developed and refined in a number of research institutions in developing countries. However, with few exceptions, they are not widely used by breeders or farmers in developing countries. Sexed sperm is commercially available in several developing countries, including Argentina, Brazil and China Theriogenology (2006).

\subsubsection{ANIMAL CLONING}

Cloning technology is already being used commercially in some parts of the world for the replication of elite breeding animals, mostly cattle and also pigs, which are used to produce animals farmed for food production. The birth of Dolly in 1996, the first animal cloned from an adult cell, was not universally celebrated. Critics of biotechnology worried that genetically modified livestock would fill the supermarket with identical copies of someone's idea of unnatural perfection. Up to 2004, about 1500 calves had been produced through somatic cell nuclear transfer (SCNT), mainly in Europe, North America, Japan and New Zealand, but also in South America and Asia Suk J, Bruce (2007). China produced the first cloned buffalo in 2004 and India followed suit in February 2009. At present the production of cloned animals is at the experimental stage in most developing countries.

\subsection{ANIMAL GENETICS AND BREEDING}

Genetic improvement of livestock depends on access to genetic variation and effective methods for exploiting this variation. Genetic diversity constitutes a buffer against changes in the environment and is a key in selection and breeding for adaptability and production on a range of environments. In developed countries, breeding programmes are based upon performance recording and this has led to substantial improvements in animal production. 
In horn of Africa the distinct disadvantages for setting up successful breeding programmes are: infrastructure needed for performance testing is normally lacking because herd sizes are normally small and variability between farms, farming systems and seasons are large; reproductive efficiency is low, due mainly to poor nutrition, especially in cattle; and communal grazing precludes implementation of systematic breeding and animal health programmes. Reproductive biotechnology provides means whereby reproductive performance may be modified at a number of points Epiz (1990). The main objectives of using reproductive biotechnologies in livestock are to increase production, reproductive efficiency and rates of genetic improvement Epitz (2005). Various biotechnology methods are used in improving the breeding stock of animals.

\subsection{CONTRIBUTIONS OF BIOTECHNOLOGY TO LIVESTOCK PRODUCTIVITY}

Biotechnology is regarded as a means to the rapid increase in agricultural production through addressing the production constraints of small-scale or resource-poor farmers who contribute more than $70 \%$ of the food produced in developing countries (Rege, 1996). Agricultural biotechnology as the solution to the problem of global food insecurity has also been reviewed by Soetan (2008b). Agricultural biotechnology has the potential to address some of the problems of developing countries like food insecurity, unfavorable environmental and climatic conditions etc mentioned above and also improve agricultural productivity.

Agricultural biotechnology has provided animal agriculture with safer, more efficacious vaccines against pseudo rabies, enteric collibacilosis and foot-and mouth disease (FMD) (Stenholm and Waggoner, 1992). Disease detection in crops and animals are more efficiently and rapidly done using DNA probes. Biotechnology as a key tool to breakthrough in medical and veterinary research has been reviewed by Soetan and Abatan, (2008).

Livestock recycle nutrients on the farm, produce valuable output from land that is not suitable for sustained crop production and provide energy and capital for successful farm operations (Delgado et al., 1999). Livestock can also help maintain soil fertility in soils lacking adequate organic content or nutrients (Ehui et al., 1998). Adding animal manure to the soil increases the nutrient retention capacity (or cation-exchange capacity), improves the soil's physical condition by increasing its water-holding capacity and improves soil structure (Delgado et al., 1999). Animal manure also helps maintain or create a better climate for micro- flora and fauna in soils.

Grazing animals improve soil cover by dispersing seeds, controlling shrub growth, breaking up soil crusts and removing biomass that otherwise might be fuel for bush fires (Delgado et al., 1999). These activities stimulate grass tilling and improve seed germination and thus improve land quality and vegetation growth. Livestock production also enables farmers to allocate plant nutrients across time and space by way of grazing to produce manure, land that cannot sustain crop production. This makes other land more productive (Delgado et al., 1999).

Biotechnology has enhanced increased animal production through Artificial insemination (AI) and also improved animal health and disease control through the production of DNA recombinant vaccines (Soetan and Abatan, 2008). Micro-organisms have broadened the 
environments they live in by evolving enzymes that allow them to metabolize numerous manmade chemicals (that is, xenobiotics) (Okpokwasili, 2007).

\section{NUTRITION AND FEED UTILIZATION}

The shortage of feed in most developing countries and the increasing cost of feed ingredients mean that there is a need to improve feed utilization. Aids to animal nutrition, such as enzymes, probiotics, single-cell proteins and antibiotics in feed, are already widely used in intensive production systems worldwide to improve the nutrient availability of feeds and the productivity of livestock.

Gene-based technologies are being increasingly used to improve animal nutrition, either through modifying the feeds to make them more digestible or through modifying the digestive and metabolic systems of the animals to enable them to make better use of the available feeds (Bedford M.R. (2000). Feeds derived from GM plants (a quarter of which are now grown in developing countries), such as grain, silage and hay, have contributed to increases in growth rates and milk yield. Genetically modified crops with improved amino acid profiles can be used to decrease nitrogen excretion in pigs and poultry. Increasing the levels of amino acids in grain means that the essential amino acid requirements of pigs and poultry can be met by diets that are lower in protein.

Metabolic modifiers have also been used to increase production efficiency (weight gain or milk yield per feed unit), improve carcass composition (meat-fat ratio), increase milk yield and decrease animal fat. The use of recombinant bovine somatotropin (rBST) in dairy cows increases both milk yield and production efficiency and decreases animal fat. In the USA, the use of rBST typically increases milk yield by $10 \%$ to $15 \%$. Although trials conducted in developing countries have reported a similar percentage increase, this increase is not significant because of the low milk yields and the high cost-benefit ratio. However, rBST is being used commercially in 19 countries where the economic returns make its use worthwhile. A porcine somatotropin has been developed that increases muscle growth and reduces body-fat deposition, resulting in pigs that are leaner and of greater market value.

livestock feeds and nutrition, improving animal health, managing natural resources relating to the livestock sector, assessing the impact of technological interventions, and strengthening the capacity of the national agricultural research systems of developing countries (24). Furthermore, the potential production capacity and contribution of livestock to the economy are still not being achieved in developing countries because the transfer, adaptation and adoption of technology is hampered by the lack of a clear policy for livestock development that is conducive to the introduction of new proven technology and by the lack of information flow from and to decision makers.

\section{EPIDEMIOLOGY AND METHODS OF DIAGNOSTICS}

Advanced diagnostic tests that use biotechnology enable the agents causing disease to be identified and the impact of disease control programmes to be monitored more precisely than was previously possible. Molecular epidemiology characterizes pathogens (viruses, bacteria, 
parasites and fungi) by nucleotide sequencing, enabling their origins to be traced. This is particularly important for epidemic diseases, in which pinpointing the source of the infection can significantly improve disease control. For example, the molecular analysis of rinderpest viruses has been vital in determining the lineages circulating in the world and instrumental in aiding the Global Rinderpest Eradication Programme. Enzyme-linked immunosorbent assays have become the standard means of diagnosing and monitoring many animal and fish diseases worldwide, and the PCR technique is especially useful in diagnosing livestock disease.

Many diagnostic techniques currently used in developing countries are cumbersome and unsuitable for low-resource settings. Molecular diagnostic technologies that are either already in use or being tested in low-income regions include polymerase chain reaction (PCR), monoclonal antibodies and recombinant antigens. These technologies can be modified to facilitate their application in the developing world Nast S. \& Singer P.A. (2002). Simple hand-held devices that rely on the binding specificity of monoclonal antibodies or recombinant antigens to diagnose infection may be easily adapted for use in settings without running water, refrigeration or electricity. Molecular characterization of the virus serotypes causing foot and mouth disease has helped in the vaccination and control programmes in Asia. In Japan and Taiwan, DNA testing is being used to diagnose hereditary weaknesses of livestock Lee S.N. \& Vajrabukka C. (1999).

\section{CONSTRAINTS ON APPLYING THE BIOTECHNOLOGY}

The application of new molecular biotechnologies and new breeding strategies to the livestock breeds used in smallholder production systems in developing countries is constrained by a number of factors. In the developing world, poverty, malnutrition, disease, poor hygiene and unemployment are widespread, and biotechnologies must be able to be applied in this context. Over the last few decades, the green revolution has brought comparative prosperity to farmers with land, but the majorities of farmers, who are landless or marginal farmers and subsist only on livestock, have been neglected and remain poor. The major constraints on applying biotechnologies have been enumerated by Madan M.L. (2003), and include: the absence of an accurate and complete database on livestock and animal owners so that programmes can be implemented, the biodiversity present within species and breeds in agro-ecological systems, the fact that models of biotechnological intervention differ distinctly between developed and developing economies, the fact that many animal species and breeds are unique to the developing world; each has its own distinct developmental, production, disease resistance and nutrient utilization characteristics, the lack of trained scientists, technicians and fieldworkers to develop and apply the technologies, both in the government and in the private sectors, the absence of an interface between industry, universities and institutions, which is necessary to translate technologies into products, the inability to access technologies from the developed world at an affordable price in order to make a rightful, positive and sustainable contribution to livestock production and the economic welfare of farmers, the high cost of technological inputs such as materials, biologicals and equipment, the failure to address issues of biosafety and to conduct risk analyses of new biologicals, gene products, transgenics and modified food items, and, above all and the negligible investment in animal biotechnology. 


\section{CONCLUSSION}

Although it is true that there is a certain bit of risk involved with the technology, this is an utmost reality that to feed a the ever growing population of the world accepting this technology is an absolute compulsory; there is no going back from here. A detailed analysis of both the advantages and the disadvantages would assist in directing the future of environmental and agricultural biotechnology, since the overall goal is to achieve a safe environment and improved agricultural productivity. The way these fears and concerns about application of biotechnology to achieving a safe environment and agriculture are addressed will have a remarkable impact on the future of biotechnology.

Although animal production is being changed significantly by advances made in thousands of biotechnology laboratories around the world, benefits are reaching the developing world in only a few areas of conservation, animal improvement, healthcare (including diagnosis and control of disease) and the augmentation of feed resources. Adopting biotechnology has resulted in distinct benefits in terms of animal improvement and economic returns to the farmers. Over the past decade, the ILRI has focused on biotechnological applications, especially in Africa, and several developing countries now have multi-institutional programmes to develop and apply biotechnology. The developing world will have to respond to the many gene based technologies now being developed with a sense of commitment, trained manpower, infrastructure and funding.

\section{Therefore, the following recommendations were forwarded:}

- In all circumstances, biotechnologies development and use requires the involvement of stakeholders in a systematic design to enhance research and development as well as transfer of the biotechnologies to target groups.

- Government and National Agricultural Research Systems are responsible for a majority of the processes required to successfully develop and transfer relevant biotechnologies.

- To deliver biotechnologies for use by target groups, there is need for cooperation between Government and benefiters.

- Hand down, more emphasis must be put to launch a massive campaign to popularize biotechnology among livestock farmers and undertake necessary steps to assist them accordingly.

\section{REFERENCES}

[1] Baccetti B \& Spadafora C (2000): Proceedings of the workshop "sperm-mediated gene transfer: advances in sperm cell research and applications." Siena, Italy May 23-6, 1999. Conclusions. Mol Reprod Dev 56, 329- 330.

[2] Barros C.M. \& Nogueira M.F.G. (2001). - Embryo transfer in Bos indicus cattle. Theriogenology, 1483-1496.

[3] Bedford M.R. (2000). - Exogenous enzymes in monogastric nutrition: their current value and future benefits. Anim. Feed Sci. Technol., 86, 1-13. 
[4] Birthal P.S., Kumar A., Ravi Shankar A. \& Pandey U.K. (1999). Sources of growth in the livestock sector. Policy paper No. 9. National Centre for Agricultural Economics and Policy Research, New Delhi, 58 pp.

[5] Daar A.S., Thorsteinsdottir H., Martin D.K., Smith A.C., Nast S. \& Singer P.A. (2002). Top ten biotechnologies for improving health in developing countries. Nature Genet., 32, 229-232.

[6] Delgado C, Rosegrant M, Steinfeld H, Ehui S, Courbois C(1999). Livestock to 2020: The next Food revolution. Food, Agriculture, and the Environment. Discussion Paper 28. IFPRI/FAO/ILRI,IFPRI, Washington, D.C.

[7] Delgado C.L., Hopkins J. \& Kelly V.A. (1998). - Agricultural growth linkages in subSaharan Africa. Research Report No. 107, International Food Policy Research Institute, Washington, $D C$, $154 \mathrm{pp}$.

[8] Ehui S, Li-Pun H, Mares V, Shapiro B (1998). The role of livestock in food security and environmental protection. Outlook on Agriculture 27(2):81-87.

[9] Food and Agriculture Organization (FAO) (2004). The State of Food and Agriculture 2003-2004. Agricultural biotechnology: meeting the needs of the poor. FAO, Rome, 209 pp.

[10] Garner DL. Flow cytometric sexing of mammalian sperm. Theriogenology 2006; 65: 943-957.

[11] Jutzi S. (2003). - Applications of gene-based technologies for improving animal production and health in developing countries. FAO/IAEA International Symposium, Vienna, Austria, 6-10 October 2003. Opening address. Food and Agriculture Organization/International Atomic Energy Agency, Vienna. Website: www.iaea.org/programmes/nafa/d3/public/opening-address-director-fao.pdf.

[12] Khoo HW (2000): Sperm-mediated gene transfer studies on zebrafish in Singapore. Mol Reprod Dev 56, 278- 280.

[13] Lavitrano M, Forni M, Bacci ML, Di Stefano C, Varzi V, Wang H \& Seren E (2003): Sperm mediated gene transfer in pig: Selection of donor boars and optimization of DNA uptake. Mol Reprod Dev 64, 284-291.

[14] Macer D.R.J. (1996). - Biotechnology, international competition, and its economic ethical and social implications in developing countries. In Concepts in biotechnology (D. Balasubramanian, C.F.A. Bryce, K. Dharmalingam, J. Green, K. Jayaraman, ed.). Universities Press Pvt. Ltd. Orient Longman Inc., Hyderabad, 378-397.

[15] Madan M.L. (2002). - Biotechnologies in animal reproduction. Key note address at international conference on animal biotechnology. Tamilnadu Vaterinary and Animal Science University, Chennai.

[16] Madan M.L. (2003). - Opportunities and constraints for using gene-based technologies in animal agriculture in developing countries and possible role of international donor agencies in promoting $R \& D$ in this field. In FAO/IAEA international symposium on applications of gene-based technologies for improving animal production and health in developing countries, Vienna, Austria, 6-10 October 2003. Food and Agriculture Organization/International Atomic Energy Agency, Vienna, 103-104.

[17] Madan ML. Animal biotechnology: applications and economic implications in developing countries. Rev Sci Tech Off Int Epitz 2005; 24(1): 127-139. 
[18] Nandi S., Raghu H.M., Ravindranatha B.M. \& Chauhan M.S. (2002). - Production of buffalo (Bubalus bubalis) embryos in vitro: premises and promises. Reprod. dom. Anim., 37, 65-74.

[19] Oishi T., Cheong I.C., Villar E.C., Lee S.N. \& Vajrabukka C. (1999). - Applied biotechnology in animal production. Issues in Asian Agriculture 1999-06-01. Food and Fertilizer Technology Center, Taiwan. Website: www.fftc.agnet.org (accessed on 2 June 2005).

[20] Okpokwasili GC (2007). Biotechnology and Clean Environment. Proc. of the 20th Annl. Conf. of the Biotechnology Society of Nigeria (BSN), 14th-17th, November, 2007 at the Ebonyi State University, Abakaliki, Nigeria.

[21] Onteru S, Ampaire A \& Rothschild M (2010) Biotechnology developments in the livestock sector in developing countries. Biotechnol Genet Eng Rev 27, 217-228.

[22] Rege JEO (1996). Biotechnology options for improving livestock production in developing countries, with special reference to Sub-Saharan Africa. In: Lebbie S.H.B.and Kagwini E. 1996. Small Ruminant Research and Development in Africa. Proc. Of the Third Biennial Conf. of the African Small Ruminant Research Network, UICC, Kampala, Uganda, 5th - 9th Dec, 1994. ILRI, Nairobi, Kenya,p. 322. http://www.fao.org/wairdocs/ilri/x5373b/x5473b05.htm.

[23] Rege JEO. Biotechnology options for improving livestock production in developing countries, with special reference to sub-Saharan Africa. http://www.fao.org/wairdocs/ilri/x5473b/x5473b05.htm [Accessed on 20.11.2013].

[24] Sansone G., Nastri M.J.F. \& Fabbrocini A. (2000). - Storage of buffalo (Bubalus bubalis) semen. Anim. Reprod. Sci., 62, 55-76.

[25] Shelton JN. Reproductive technology in animal production. Rev Sci Tech Off Int Epiz 1990; 9(3): 825-845.

[26] Squire KR, Embretson JE \& First NL (1989): In vitro testing of a potential retroviral vector for producing transgenic livestock. Am J Vet Res 50, 1423-1427.

[27] Stenholm CW, Waggoner DB (1992). Public Policy and Animal Biotechnology in the 1990s: Challenges and Opportunities. In: Animal Biotechnology - Opportunities and Challenges (Ed MacDonald, June F.) NABC National Agricultural Biotechnology Council, Ithaca, New York, Report 4: 25-35.

[28] SukJ, Bruce A, Gertz R, Warkup C, Whitelaw CBA, Braun A, Oram C, Rodríguez-Cerezo E, Papatryfon I. Dolly for dinner? Assessing commercial and regulatory trends in cloned livestock. Nature Biotechnology 2007; 25: 47- 53.

[29] Vishwanath R. \& Shannon P. (2000). - Storage of bovine semen in liquid and frozen state. Anim. Reprod. Sci., 62, 23-53. 